\title{
ABCS OF SCIENCE PR
}

By Bernard Dixon

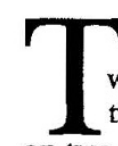
wo different meetings with participants drawn from two very different industries. Two different speakers, on two different topics, on two different dates in two different countries. But the message was essentially the same. It is one that all concerned with the public relations of science need to learn, re-learn, and then learn all over again.

First, Harold Bolter, the Corporate Affairs Director of British Nuclear Fuels (BNFL), speaking in London at last month's International Risk Assessment Conference. Bolter described a sharp switch in policy that had narrowly averted what could have been a major catastrophe for his beleaguered industry. The story began a few years ago when the company sought to transform its lowly standing by mounting a nationwide advertising crusade. The premise was that journalistic bias prevented the nuclear industry from getting its messages across without distortion to the citizens of Britain. The obvious solution was to buy time on television and radio, and space in newspapers and magazines, to correct misconceptions and place the real facts before the public.

BNFL asked one of Britain's top agencies to develop a campaign highlighting the safety of nuclear reactors and the minuscule risk from the tiny amounts of radioactivity they put out into the environment. The agency duly developed what Bolter called "some impressive-looking concepts,"which were then shown to groups representative of the U.K. public. "The result was a disaster," Bolter said. "The test panels did not like the advertisements. Worse, they simply did not believe what we were telling them. Our fundamental mistake was to assume that we had credibility with the public. The research proved that we did not. The reason? Rightly or wrongly, we were seen as secretive-prone to cover up embarrassing facts-and untrustworthy. Because we had no credibility, any positive statements we made about our operations would be totally counter-productive. People automatically rejected such claims simply because they came from BNFL."

So the campaign was aborted in favor of a thorough rethink. Out went the glossy ads. Out went the reassuring words about safety. Instead, BNFL simply invited the public, through television and the press, to come to Sellafield, Britain's largest nuclear site, to see for themselves what went on there. The response was overwhelming-so much so that less than a year later the company had to build a new Visitors' Center and organize guided coach tours around the various plants on the site. Around 130,000 people per annum now visit Sellafield, which has become the most popular tourist attraction in the entire County of Cumbria.

Compared with the situation before the aborted media blitz, and with the deep suspicion of BNFL revealed by the pilot tests, the new strategy has worked amazingly well. The latest polls at the Visitors' Center show that while 57 percent of people are fairly or very pro-nuclear when they arrive, the figure rises to 79 percent when they leave. The corresponding percentages for antis are 16 and 9 . Moreover, while it would take 350 years for the entire adult population of Britain to pass through the portals at the current rate of attendance, the Center has a positive influence on millions of people who never ever visit Sellafield. The messages clearly conveyed by the Centers' advertising are that BNFL is not a secretive or dishonest company and that Sellafield must be a safe place.

Exactly one week after hearing Harold Bolter's address, I was in Copenhagen as a member of the European Federation of Biotechnology's Task Group on Public Perceptions of Biotechnology, listening to a talk by Mike Rulis, Director of Corporate Communications for Novo Nordisk, on his company's approach to public information. In part paralleling, in part complementing, the BNFL story, it was a talk that spelled out the shrewd yet sensitive tactics used by this major Danish corporation as it entered the potentially explosive field of gene technology with products such as recombinant human insulin.

Seven or eight years ago, Novo Nordisk decided quite consciously not to target the media in explaining the safety and benefits of genetically engineered products. "We believed we were in a no-win position vis-a-visjournalists," Rulis said. "Equally important, we did not at that time have a success story to tell." Rather than courting journalists, therefore, the company resolved to focus its attention on employees, interest groups, and local and national politicians and residents in areas with Novo Nordisk factories. Initiatives included meetings across the table with interested parties, and use of the company's own neighborhood newspapers to explain genetic manipulation, and its regulation, to people working in and living close to company plants.

Only later, when there was positive news to convey, did Rulis and his colleagues make a splash with the national media. This came with the launch of Lipolase, the first genetically engineered fat-splitting enzyme to be incorporated in detergents. The reporting of this breakthrough was almost wholly positive, accurate and responsible.

Novo Nordisk drew four conclusions from its experiences. First, one of the most effective techniques for addressing public concern is small face-to-face meetings. Second, it is easier to prevent myths from developing than to deal with them afterwards. Third, timing is crucial in handling the media, which by definition are not the primary target. Fourth, the public must be informed by public bodies; corporate prestige advertising is counter-productive.

From these two stories we can, I think, distill one common message. Openness, humility, and carefully targeted, proactive measures comprise the formula through which large organizations, commercial or otherwise, can assuage the public suspicion they are inherently likely to provoke. Glitzy advocacy is not the answer. 